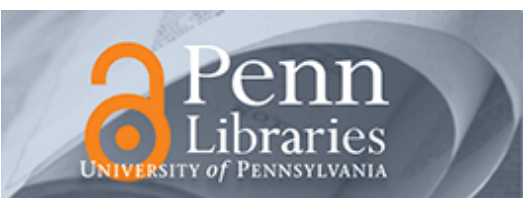

University of Pennsylvania

ScholarlyCommons

9-7-2006

\title{
Characterization of Gene Expression Profiles of Normal Canine Retina and Brain Using a Retinal cDNA Microarray
}

\author{
Gerardo L. Paez \\ Kimberly F. Sellers \\ Mark Band \\ Gregory M. Acland \\ Barbara Zangerl
}

See next page for additional authors

Follow this and additional works at: https://repository.upenn.edu/vet_papers

Part of the Comparative and Laboratory Animal Medicine Commons, and the Ophthalmology

\section{Commons}

\section{Recommended Citation}

Paez, G. L., Sellers, K. F., Band, M., Acland, G. M., Zangerl, B., \& Aguirre, G. D. (2006). Characterization of Gene Expression Profiles of Normal Canine Retina and Brain Using a Retinal cDNA Microarray. Molecular Vision, 12 1048-1056. Retrieved from https://repository.upenn.edu/vet_papers/146

Paez, G. L., Sellers, K. F., Band, M., Acland, G. M., Zangerl, B., \& Aguirre, G. D. (2006). Characterization of gene expression profiles of normal canine retina and brain using a retinal cDNA microarray. Molecular Vision, 12, 1048-1056. http://www.molvis.org/molvis/v12/a118/

This paper was published by Molecular Vision under a CC BY-NC-ND 3.0 license.

This paper is posted at ScholarlyCommons. https://repository.upenn.edu/vet_papers/146

For more information, please contact repository@pobox.upenn.edu. 


\title{
Characterization of Gene Expression Profiles of Normal Canine Retina and Brain Using a Retinal cDNA Microarray
}

\begin{abstract}
Purpose: Construction of a canine retinal custom cDNA microarray for comprehensive retinal gene expression profiling and application for the identification of genes that are preferentially expressed in the retina and brain lobes using a brain pool reference tissue.

Methods: A cDNA microarray was constructed utilizing clones obtained from a normalized canine retinal expressed sequence tag library. Gene expression profiles were analyzed for normal retina, as well as the cortex of the frontal, occipital, and temporal brain regions. Each sample was studied against a reference sample of pooled brain RNA. Data from a quantified scanned image were normalized using the loess subgrid procedure. Retina-enriched genes were identified using the Significance Analysis of Microarrays (SAM) algorithm, and confirmed by northern blot analyses for selected genes. Differences between biological samples were displayed using principal component analysis (PCA).

Results: Expression profiles for each tissue set were analyzed against the common reference of pooled brain. Changes in expression between the sample and the reference were higher in the retina (27.9\%) than the individual brain tissues (2-6.6\%). Furthermore, all individual retinal samples were clearly separated from any of the hybridizations using brain tissue in the PCA. The accuracy of observed changes in expression has been confirmed by northern blot analysis using five randomly chosen genes that represented a wide range of different expression levels between retina and brain.

Conclusions: We have established an accurate and robust microarray system suitable for the investigation of expression patterns in the retina and brain. Characterization of the gene expression profiles in normal retina will facilitate the understanding of the processes that underline differences between normal and diseased retinas.

\section{Disciplines}

Comparative and Laboratory Animal Medicine | Medicine and Health Sciences | Ophthalmology | Veterinary Medicine

\section{Comments}

Paez, G. L., Sellers, K. F., Band, M., Acland, G. M., Zangerl, B., \& Aguirre, G. D. (2006). Characterization of gene expression profiles of normal canine retina and brain using a retinal cDNA microarray. Molecular Vision, 12, 1048-1056. http://www.molvis.org/molvis/v12/a118/
\end{abstract}

This paper was published by Molecular Vision under a CC BY-NC-ND 3.0 license.

\section{Author(s)}

Gerardo L. Paez, Kimberly F. Sellers, Mark Band, Gregory M. Acland, Barbara Zangerl, and Gustavo D. Aguirre 


\title{
Characterization of gene expression profiles of normal canine retina and brain using a retinal cDNA microarray
}

\author{
Gerardo L. Paez, ${ }^{1}$ Kimberly F. Sellers, ${ }^{2}$ Mark Band,${ }^{3}$ Gregory M. Acland, ${ }^{4}$ Barbara Zangerl, ${ }^{1}$ Gustavo D. Aguirre ${ }^{1}$ \\ ${ }^{1}$ Department of Clinical Studies - Philadelphia, School of Veterinary Medicine, University of Pennsylvania, Philadelphia, PA; \\ ${ }^{2}$ Department of Mathematics, Georgetown University, Washington, DC; ${ }^{3}$ W. M. Keck Center for Comparative and Functional \\ Genomics, University of Illinois, Urbana, IL; ${ }^{4}$ Baker Institute, College of Veterinary Medicine, Cornell University, Ithaca, NY
}

\begin{abstract}
Purpose: Construction of a canine retinal custom cDNA microarray for comprehensive retinal gene expression profiling and application for the identification of genes that are preferentially expressed in the retina and brain lobes using a brain pool reference tissue.

Methods: A cDNA microarray was constructed utilizing clones obtained from a normalized canine retinal expressed sequence tag library. Gene expression profiles were analyzed for normal retina, as well as the cortex of the frontal, occipital, and temporal brain regions. Each sample was studied against a reference sample of pooled brain RNA. Data from a quantified scanned image were normalized using the loess subgrid procedure. Retina-enriched genes were identified using the Significance Analysis of Microarrays (SAM) algorithm, and confirmed by northern blot analyses for selected genes. Differences between biological samples were displayed using principal component analysis (PCA).

Results: Expression profiles for each tissue set were analyzed against the common reference of pooled brain. Changes in expression between the sample and the reference were higher in the retina (27.9\%) than the individual brain tissues (2$6.6 \%$ ). Furthermore, all individual retinal samples were clearly separated from any of the hybridizations using brain tissue in the PCA. The accuracy of observed changes in expression has been confirmed by northern blot analysis using five randomly chosen genes that represented a wide range of different expression levels between retina and brain.

Conclusions: We have established an accurate and robust microarray system suitable for the investigation of expression patterns in the retina and brain. Characterization of the gene expression profiles in normal retina will facilitate the understanding of the processes that underline differences between normal and diseased retinas.
\end{abstract}

The domesticated dog, Canis familiaris, exhibits a diverse repertoire of morphological and behavioral characteristics that define the numerous specific breeds. This segregation, in effect the creation of genetic isolates, has resulted in the emergence of autosomal recessive inherited canine diseases that are often directly comparable to those observed in humans. Many of these affect the retina and result in a large group of genotypically distinct retinal disorders representing molecular and phenotypic counterparts in humans. By far the largest group of diseases in dog, termed progressive retinal atrophy (PRA), serve as disease homologs for retinitis pigmentosa (RP) in humans [1]. Although the final common pathway of photoreceptor degeneration in many retinal degenerative processes appears to be apoptosis [2-4], it is likely that differing mechanisms link the causative mutations to the cell death processes. Insights into these mechanisms are critical to develop therapeutic strategies, and these studies are dependent on animal models. One approach to examine the pathways involved in retinal degenerative diseases in animal models is gene expression profile analysis with the aim of identifying early alterations in gene expression that contribute to photoreceptor cell death [5]. The microarray technology shows

Correspondence to: Barbara Zangerl, Section of Ophthalmology, School of Veterinary Medicine, University of Pennsylvania, 3900 Delancey Street, Philadelphia, PA, 19104; Phone: (215) 898-6068; FAX: (215) 573-2162; email: bzangerl@vet.upenn.edu potential as a useful tool to identify genes and gene pathways involved in ocular disease progression and may therefore aid in the characterization and classification of these diseases, possibly identifying a common mechanism linking disorders into groups [6,7].

Microarrays have been useful in the simultaneous analysis of transcript levels of thousands of genes in different physiological states of an organism, tissue, or cell $[8,9]$. Construction of microarrays is most efficient when information is utilized from annotated genomes or expressed sequence tags (ESTs) and has led to new insights into animal development, cancer, infectious diseases, and aging [10-12]. A major limitation of the technique is the analysis of sequences represented on the array. This disadvantage is particularly problematic when analyzing highly specialized tissues such as the retina due to the repertoire of uniquely or preferentially expressed genes contributing to its structure and function. In the case of "orphan" species, commercial arrays are either not available or targeted to a broader research community and underrepresent the tissue of interest. The current available canine microarray is based on transcripts representing 11 nonretina tissues and gene predictions not supported by experimental data (Affymetrix Genechip ${ }^{\circledR}$ Canine Genome Array, Santa Clara, CA). To obtain insight into intrinsic processes of the canine and human retina, great efforts are directed toward the identification and characterization of transcripts with functional relevance to this tissue [13-15]. Despite these ad- 
vances, a remaining challenge is to obtain an expression map of the canine retina/retinal pigmented epithelium transcriptome, further facilitating the identification of retinal susceptibility genes but, most importantly, offering an invaluable resource for functional genomics studies.

To overcome these limitations and drive the development of the canine retina transcriptome, we selected about 4,500 genes from a normalized canine retinal EST database [16]. These were used to construct a canine retinal cDNA microarray for expression profiling of genes that are of interest in studies of normal development and function and pathological conditions of the retina. As the brain and retina have a common embryological origin, a brain pool was initially validated as a reference sample for comparing expression profiles in multiple samples from animals with different molecularly defined retinal diseases and at different stages of the disorders. As part of this study, we have compared gene expression profiles between normal retina and different regions of the brain cortex (frontal, occipital, temporal) to identify those genes preferentially expressed in either tissue. The overall aim of this study is the identification of retina specific gene expression patterns that will maximize the use in a variety of PRA dog models $[1]$.

\section{METHODS}

Tissue collection and RNA preparation: Retinas and brain samples were collected from three 16-week-old normal beagles (two males and one female) that were part of a specific-pathogen-free (SPF) colony at Cornell University. In addition, retinas and spleen samples were obtained from two 16-week-old crossbred dogs (one male and one female) that were part of NEI/NIH sponsored projects (R01EY06855, R01EY13132) and were kept at the Retinal Disease Studies Facility (RDSF) in Kennett Square, PA. All dogs were housed in an indoor kennel under $12 \mathrm{~h}$ cyclic light conditions, and eyes were collected at a single time period (noon) to avoid potential fluctuations in retinal gene expression with time of day [17-22]. Both eyes were enucleated from the light-adapted dogs following intravenous anesthesia with sodium pentobarbital, and the dogs were euthanized after enucleation with an overdose of the barbiturate. The retinas were collected within 1-2 min after enucleation, and brain and spleen samples obtained within 5-10 min after euthanasia; all tissues were flash frozen in liquid nitrogen and stored at $-80{ }^{\circ} \mathrm{C}$ until use. The research was conducted in full compliance with the ARVO Resolution on the Use of Animals in Research.

RNA isolation: Total RNA was isolated using Trizol reagent (Invitrogen, Carlsbad, CA) and further purified by RNeasy mini kit (Qiagen, Valencia, CA). Purity and RNA quality were evaluated by absorbance at $260 \mathrm{~nm}$ and by denaturing formaldehyde agarose gel electrophoresis. High quality RNAs with $\mathrm{A}_{260} / \mathrm{A}_{280}$ ratio over 1.8 and intact $28 \mathrm{~S}$ and $18 \mathrm{~S}$ RNA bands were used for microarray analysis. To generate an RNA reference sample for microarray hybridizations, we pooled equal amounts of total RNA from the cortex of the occipital, temporal, and frontal brain regions collected from three 16-week-old beagles to achieve a homogeneous pool of transcripts. The pooled RNA was divided into aliquots $(2 \mu \mathrm{g} /$ $\mu \mathrm{l}$ ) and stored at $-80^{\circ} \mathrm{C}$ until use. For the purpose of this work, four tissue groups have been established, containing five biological replicates for normal retina and three for each respective brain region. After initial validation of reproducibility, only one microarray experiment was used for each sample.

Microarray construction: For microarray production, 3,931 "UniGene" sequences are represented by individual clones from a canine retinal EST library [16]; another 120 unique sequences were added by two clones each to ensure complete coverage of cDNA. In addition, about 300 genes resulting from retinal subtraction libraries [16] or serving as controls were printed on the microarray. Each clone was picked from glycerol stocks manually, inoculated in $50 \mu \mathrm{l}$ of LB Broth Base (Invitrogen) with $100 \mu \mathrm{g} / \mathrm{ml}$ ampicillin and grown overnight at $37^{\circ} \mathrm{C}$. PCR was performed in two $15 \mu \mathrm{l}$ reactions for each clone by dipping the template into a master mix $(1.5 \mu \mathrm{M}$ $\mathrm{MgCl}_{2}, 0.2 \mu \mathrm{M}$ dNTP, $0.4 \mu \mathrm{M}$ of each primer [T7: 5'-TAA TAC GAC TCA CTA TAG GG-3'; Sp6: 5'-ATT TAG GTG ACA CTA TAG-3'] and 1 U Taq polymerase) with a replicator, and amplified for 40 cycles at $94{ }^{\circ} \mathrm{C}$ for $10 \mathrm{~s}, 54{ }^{\circ} \mathrm{C}$ for $20 \mathrm{~s}$ and $72{ }^{\circ} \mathrm{C}$ for $1 \mathrm{~min}$, after an initial denaturing step at $95{ }^{\circ} \mathrm{C}$ for $1 \mathrm{~min}$, and followed by a final extension at $72^{\circ} \mathrm{C}$ for 10 min. PCR products for each clone were pooled and purified using Millipore Montage PCR $_{384}$ Filter Plates (Millipore, Billerica, MA). PCR products were resuspended in $50 \mu \mathrm{l}$ of distilled water, and $6 \mu \mathrm{l}$ were run on a $1 \%$ agarose gel. Rhodopsin, $(R H O)$, and $\beta$-Actin $(A C T B)$ were used as positive controls, while microsatellite locus CUX20001 [23] was used as a genomic control spot. All PCR products plus Array Control $^{\text {TM }}$ PCR Spots (Ambion, Austin, TX; spots 1-8) were spotted on Telechem superamine glass slides (TeleChem International, Inc., Sunnyvale, CA) using a Cartesian Pysix 5000 printer.

Microarray hybridization and scanning: Ten $\mu \mathrm{g}$ of pooled canine brain total RNA was hybridized against $10 \mu \mathrm{g}$ of the respective test sample. Tissues were fluorescent-labeled using an indirect labeling protocol (3 DNA Array Kit, Genesphere, Inc. Hatfield, PA) following the manufacturer's protocol. Hybridization signals were visualized with $\mathrm{Cy} 5$ and Cy3 fluorescent reporter molecules, and intensities were detected using a GenePix 4000B Scanner (Molecular Devices Corporation, Union City, CA). Scanned images were processed using GenePix Pro version 6.0 (Molecular Devices Corporation, Downington, PA). The main quantities of interest produced by the image analysis (segmentation and background correction) are the $(R, G)$ fluorescence intensity pairs for each gene on each array $(R=$ red for $\mathrm{Cy} 5$, and $\mathrm{G}=$ green for $\mathrm{Cy} 3$ ). Loess (locally weighted regression) normalization was performed to remove systematic variation that occurs in every microarray experiment. An MA plot was used to represent the $(R, G)$ data, where $M=\log _{2}(R / G)$ and $A=\log _{2}(R G)$ [24]. For complete consideration surrounding the normalization process, loess normalization over the entire chip, and block-specific loess normalization followed by additional scaling via maximum likelihood estimation (MLE) or median absolute deviation (MAD) were also studied. 
Statistical analysis: Each hybridization was annotated according to MIAME (Minimal Information About a Microarray Experiment) standards, and analyzed with GeneSpring version 7.2 (Silicon Genetics, Agilent Technologies, Palo Alto, CA; GPL3951, GPL3957, and GSE5208). Controls were used for quality control and normalization of the microarrays using GeneSpring, but ignored for the statistical data analysis. Significant changes in expression were identified with Significance Analysis of Microarrays (SAM, 1.15, Stanford University, Palo Alto, CA) [25] at a delta value resulting in a false discovery rate (FDR) of less than $10 \%$. Only statistically significant changes will be reported here; however, the entire dataset is available from the authors on request.

Principal component analysis (PCA) was performed on a complete microarray dataset consisting of log-transformed expression values for each individual replicate. As a result, the dimensionality of the dataset was reduced and described in a series of axes that explain the variance within the data. In this analysis, $30.4 \%, 16.98 \%$, and $14.1 \%$ of the variance within the data was accounted for by the $\mathrm{X}, \mathrm{Y}$, and $\mathrm{Z}$ axes, respectively. These were used to plot the data and give an impression of the variation between the individual datasets; distances between points on the graph are indicative of the differences between replicates.

Northern analysis: Northern analysis was used to confirm expression patterns observed in the microarray data. Total RNA $(10 \mu \mathrm{g})$ from brain (equal representation of frontal, temporal, and occipital cortex regions), retina and spleen were separated on a $1 \%$ formaldehyde-agarose gel and transferred to a membrane (GeneScreen Plus Hybridization Transfer Membrane, Perkin Elmer Life Sciences, Inc. Boston, MA). The RNA was crosslinked to the membrane and hybridized to purified cDNA probes labeled with $\left[\alpha^{32} \mathrm{P}\right] \mathrm{dCTP}$ using a DNA-labeling system (RadPrime DNA Labeling System, Invitrogen) at $68^{\circ} \mathrm{C}$ overnight using ExpressHyb Solution (Clonetech, Palo Alto, CA), and washed in $2 \mathrm{X}$ SSC, $0.05 \% \mathrm{SDS}$, and $0.1 \%$ SSC, $0.05 \%$ SDS for 40 min each.

Probes for northern analysis were obtained by RT-PCR with primers designed from the corresponding cDNA clone information [16] (Appendix 1). For RT-PCR, $0.5 \mu \mathrm{g}$ of total RNA was incubated in a reaction mixture containing primer (50 $\mu \mathrm{M}$ oligo(dT) ${ }_{20}$, or $50 \mathrm{ng} / \mu 1$ random primer), $10 \mu \mathrm{M}$ of dNTPs mix, $40 \mathrm{U} / \mu \mathrm{l}$ of RNase inhibitor, ThermoScript ${ }^{\mathrm{TM}} \mathrm{RT}$ (15 U/ $\mu \mathrm{l}$; Invitrogen), $25 \mathrm{mM}$ of $\mathrm{MgCl}_{2} 10 \mathrm{X}$ cDNA synthesis buffer in a final volume of $25 \mu \mathrm{l}$. The samples were incubated at $70{ }^{\circ} \mathrm{C}$ for $5 \mathrm{~min}$ to denature the RNA then put on ice and amplified as follows: $94{ }^{\circ} \mathrm{C}, 1 \mathrm{~min} ; 50-63{ }^{\circ} \mathrm{C}, 1 \mathrm{~min} ; 72^{\circ} \mathrm{C}$ for $1 \mathrm{~min}$, for 35 cycles. The RT-PCR product was fractionated by electrophoresis on a $1.4 \%$ agarose gel containing $1 \mu \mathrm{g} / \mathrm{ml}$ ethidium bromide in $1 \mathrm{X}$ TAE buffer. Each membrane was also hybridized with canine $A C T B$ cDNA to normalize for RNA loading, and image intensities of the blots were quantified using a Bio-Imaging Analyzer-BAS 1000 (Fujifilm life Science, Tokyo, Japan) and its associated software.

\section{RESULTS}

We produced a custom-made microarray chip featuring about 4,500 retina-specific genes to investigate expression profiles of the retina. First experiments evaluating reproducibility found negligible variance between technical replicates (data not shown). To allow cross-comparison between multiple conditions, the experiment was arranged as reference design thus allowing for an equal standardized error between each individual comparison and avoiding dye bias. Therefore, each biological sample was hybridized only once. Given the differences in test and reference sample, different normalization approaches were considered: block-specific loess normalization (subgrid normalization), general loess normalization on the entire array (global normalization), and subgrid loess normalizations followed by either a MLE or MAD scaling procedure (Appendix 1). This confirmed that the subgrid normalization, as performed by GeneSpring, did not introduce data bias, and was used for the presented results.

The canine retinal cDNA microarray was used to identify genes preferentially expressed in normal 16-week-old retina in comparison to a pooled brain reference sample. Quantitative differences in the level of gene expression are illustrated in a scatter plot (Figure 1) comparing the expression level for normal retina (X-axis) versus the expression level from the brain pool (Y-axis). High abundance of tissue-specific transcripts is observed in spots located outside the two-fold expression lines (Figure 1, lines 2 and 3). SAM was used with a FDR of $10 \%$, to confirm that $13.2 \%$ of 3,070 valid genes strongly hybridized to retinal cDNA targets, implying that 405 genes on the microarray are preferentially expressed in the normal retina (Table 1, Appendix 1). Of the remainder, 2,213 transcripts showed equal expression between normal retina and the brain pool reference tissue, and 14.7\%, 452 genes, were less abundant in the retina (Table 2). Note that we call the spotted DNA sequences "genes" whether they correspond to actual genes or ESTs.

To further characterize the genes found to be preferentially expressed in brain, we hybridized the same brain pool against cortex of frontal, occipital, and temporal brain regions of three the different animals. Three percent of 3,489 valid transcripts hybridized preferentially with the frontal region; this corresponds to 114 genes highly expressed in the frontal cortex. The occipital and temporal regions, respectively, had 22 and 20 genes (of 2,089 and 2,289 valid transcripts, respectively) that were more abundant. Most transcripts were unique to a single cortex area (Figure 2A, Table 3), and only two genes were upregulated in all three brain regions (DR010012A10F04, TM4SF1). Transcripts less abundant than in the pooled reference also demonstrated a low overlap between brain regions (Figure 2B, Table 4), with one gene downregulated in all three brain cortex areas (FLJ10159).

The obtained expression profiles were analyzed using PCA revealing independent clustering of experiments derived from retinal and brain samples (Figure 3). The PCA profile demonstrates that a specific normal retinal gene expression profile differs from the expression profiles of the frontal, occipital, 


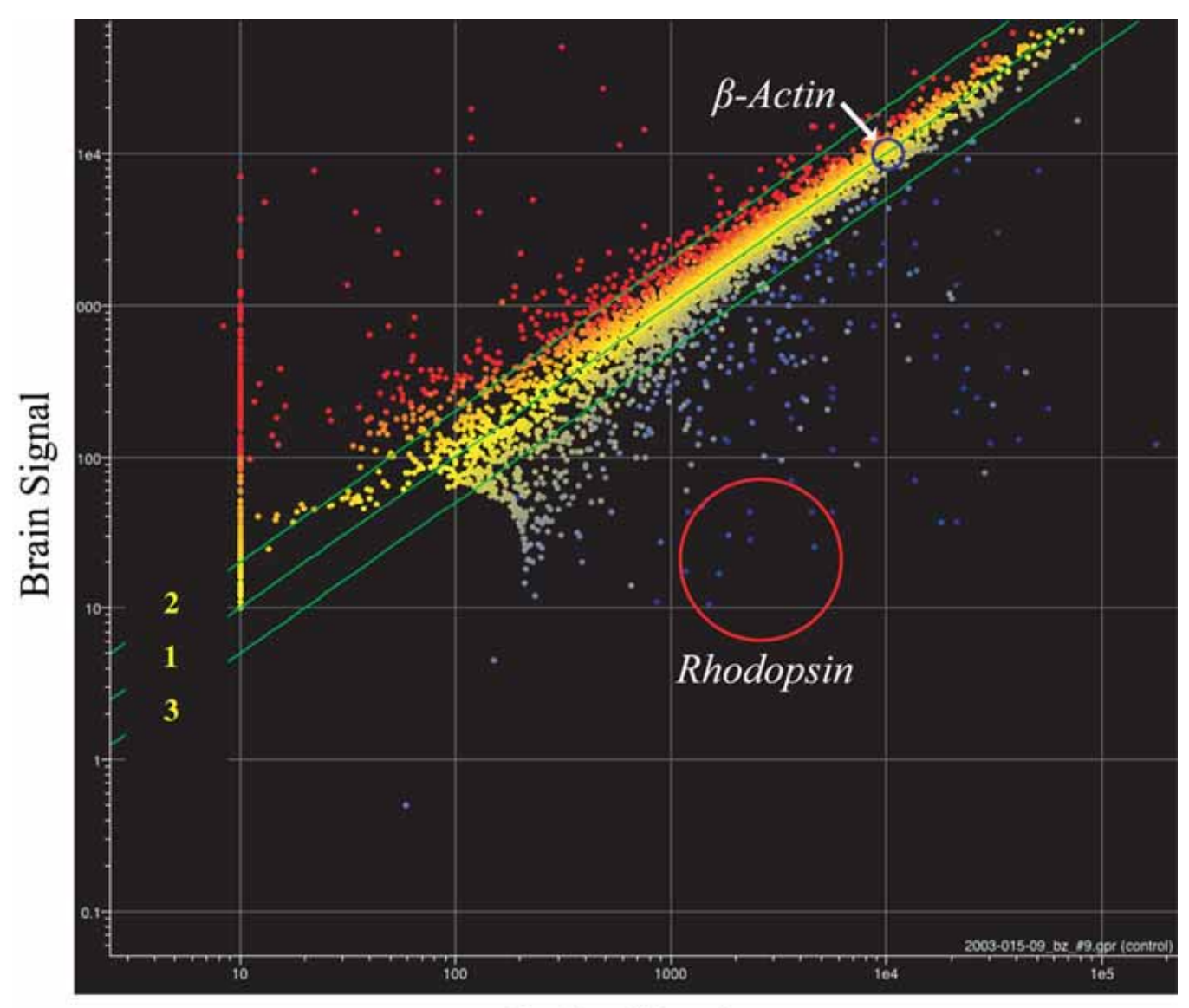

Figure 1. MA-plot comparing gene expression in retina and brain reference pool. Each point represents a single transcript/spot on the array, plotted as a function of its signal amplitude (expression level) for brain pool and retina. Line 1 denotes equivalent expression in retina and brain, whereas lines 2 and 3 indicate a twofold difference in the signal strength. For illustration, spots representing Rhodopsin, much more abundant in retina than brain, are located within the red circle, while the uniformly expressed $\beta$ Actin spots lie within the blue circle.

Retina Signal

TABLE 1. FunCTIONAL ANNOTATION OF THE TOP 30 RETINA-ENRICHED GENES

\begin{tabular}{|c|c|c|c|c|c|c|c|c|}
\hline $\begin{array}{l}\text { Clone } \\
\text { identifier }\end{array}$ & $\begin{array}{c}\text { GenBank } \\
\text { access } \\
\text { number }\end{array}$ & Dog chromosome location & $\begin{array}{l}\text { Gene } \\
\text { symbol }\end{array}$ & $\begin{array}{l}\text { Gene ID } \\
\text { number }\end{array}$ & $\begin{array}{l}\text { Human } \\
\text { chromosome }\end{array}$ & Unigene & $\begin{array}{l}\text { Retina/brain } \\
\text { fold change }\end{array}$ & Function \\
\hline DR010009B10H06 & DT538190 & $25: 47,884,218-47,884,349$ & SAG & 6295 & 2937.1 & Hs.308 Cfa. 7077 & 37 & Rhodopsin-mediated signaling \\
\hline DR010020A20B07 & DT540322 & $14: 21,958,280-21,958,543$ & GNAT1 & 2779 & $7 \mathrm{q} 12.3$ & Hs. 648519 Cfa.3191 & 36.5 & Transport, visual system \\
\hline DR010017A21C10 & DT539700 & $7: 22,113,973-22,114,385$ & PDC & 5132 & $1 \mathrm{q} 31.1$ & Hs. 580 Cfa. 1202 & 36 & Signal, visual system \\
\hline DR010018A20D11 & DT539956 & $15: 54,570,842-54,571,430$ & SFRP 2 & 6423 & $4 \mathrm{q} 31.3$ & Hs. 481022 & 31.5 & Unknown \\
\hline DR010017A21D08 & DT539707 & $20: 8,475,328-8,475,483$ & RHO & 6010 & $3 q 21-q 24$ & Hs. 247565 Cfa. 7396 & 27.5 & Signal, visual system \\
\hline DR010024A10D06 & DT541291 & $11: 9,365,437-9,365,294$ & & & 9q32 & Hs. 150406 & 26 & EST \\
\hline DR010013B10A12 & DT538991 & $3: 94,958,572-9,958,849$ & PDE6B & 399653 & 10p14 & Hs.59872 Cfa.3793 & 25 & Signal, visual system \\
\hline DR010015B10D11 & DT539417 & $18: 64,384,884-64,385,136$ & ROM1 & 6094 & $11 \mathrm{q} 12.3$ & Hs. 281564 & 24.5 & Disk morphogenesis \\
\hline DR010030A20H09 & DT543034 & $4: 35,677,194-35,677,735$ & & & $10 \mathrm{q} 23.1$ & & 23 & EST \\
\hline DR010008B20F 12 & DT538002 & $20: 53,894,125-53,894,570$ & RDH8 & 50700 & $19 \mathrm{p} 13.2$ & Hs. 272405 & 21 & Transport, visual system \\
\hline DR010023B10C07 & DT541135 & $17: 37,457,058-37,457,430$ & DUSP 2 & 1844 & $2 \mathrm{q} 11.2$ & Hs.1183 & 20.5 & Nucleic acid metabolism \\
\hline DR010022A20E08 & DT540832 & $12: 51,422,323-51,422,562$ & & & $6 \mathrm{q} 15$ & Hs. 520287 & 16 & EST \\
\hline DR010018B20H08 & DT540046 & $2: 87,515,835-87,515,994$ & & & $1 \mathrm{p} 36.22$ & Hs. 439194 & 11 & EST \\
\hline DR010008B20G12 & DT538006 & $7: 69,939,004-69,939,305$ & CLUL1 & 27098 & $18 \mathrm{p} 11.32$ & Hs. 274959 Cfa. 3516 & 9.30 & Unknown \\
\hline DR010028B20H07 & DT542573 & $27: 4,960,724-4,961,087$ & NEUROD 4 & 58158 & $12 \mathrm{q} 13.2$ & Hs.131010 & 9.5 & Metabolism \\
\hline DR010028B10E10 & DT542509 & $17: 51,086,234-51,086,428$ & NLR & 4901 & $14 \mathrm{q} 11.1-\mathrm{q} 11.2$ & Hs. 89606 & 9 & DNA, visual system \\
\hline DR010029A10E09 & DT542612 & $6: 19,524,381-19,524,521$ & KCTD13 & 253980 & $16 \mathrm{p} 11.2$ & Hs. 534590 & 9 & DNA metabolism \\
\hline DR010009B10A10 & DT538119 & $28: 32,984,199-32,984,621$ & INPP $5 F$ & 22876 & $10 \mathrm{q} 26.12$ & Hs. 369755 & 6.5 & Metabolism \\
\hline DR010022B20B07 & DT540940 & $8: 35,335,208-35,335,594$ & OTX2 & 5015 & $14 \mathrm{q} 21-\mathrm{q} 22$ & Hs. 288655 & 6 & Metabolism \\
\hline DR010021B20E07 & DT540724 & $20: 38,082,009-38,082,300$ & LRTM1 & 57408 & $3 p 14.3$ & Hs. 554867 & 6 & Sensory organ development \\
\hline DR010019B20C09 & DT540148 & $14: 58,294,157-58,294,685$ & & & $7 \mathrm{q} 31.2$ & Hs. 239676 & 5 & EST \\
\hline DR010014B20E10 & DT539271 & $5: 37,315,043-37,315,421$ & & & $6 \mathrm{p} 21.1$ & & 5 & EST \\
\hline DR010011A20D01 & DT538558 & $18: 9,132,499-9,132,941$ & ECOP & 81552 & $7 \mathrm{p} 11.2$ & Hs. 488307 & 4.5 & Signal transducer activity \\
\hline DR010005B10H02 & DT537179 & $5: 59,339,081-59,339,539$ & GNB1 & 2782 & $1 \mathrm{p} 36.33$ & Hs. 430425 & 4.50 & Signal transducer activity \\
\hline DR010016B20C07 & DT539561 & $2: 74,241,431-74,241,808$ & HMG-17 & 403686 & $13 \mathrm{p} 25.1$ & Hs. 477784 Cfa. 3549 & 4 & Nucleic acid \\
\hline DR010024B10C12 & DT541427 & $22: 7,990,538-7,990,876$ & HMGN2 & 3151 & $1 \mathrm{p} 36.11$ & Hs.181163 & 4 & Nucleic acid \\
\hline DR010017B10E11 & DT539798 & $23: 35,612,629-35,613,006$ & & & $11 \mathrm{q} 12.3$ & Hs. BC041359 & 4 & EST \\
\hline DR010027B20E09 & DT542265 & $12: 67,236,366-67,236,647$ & GLTP & 51228 & $12 \mathrm{q} 24.11$ & Hs. 381256 & 4 & Transport \\
\hline DR010006B20G02 & DT537497 & $2: 78,953,814-78,954,066$ & DDOST & 1650 & $1 \mathrm{p} 36.12$ & Cfa. 3884 & 3.5 & Metabolism \\
\hline DR010029B10D10 & DT542720 & $26: 11,674,727-11,675,099$ & PPP1CC & 5501 & $12 \mathrm{q} 24.11$ & Hs.79081 Cfa.451 & 3.5 & Metabolism \\
\hline DR010007A10G09 & DT537586 & $33: 26,792,981-26,793,197$ & & & $3 q 13.33$ & Hs.333358 & 3.5 & EST \\
\hline
\end{tabular}

The top 30 genes with preferential retinal expression in a retina-brain pool comparisons are listed, with the corresponding identifiers, chromosomal location, expression ratio, and function. Hs represents Homo sapiens, Cfa represents Canis familiaris. 
and temporal cortices of the brain, while these clusters are closely related. Within groups, experiments showed little variation, and the retinal profiles did not significantly differ with regard to litter or sex of the tested individuals. The brain lobe regions showed tissue-specific expression patterns, but one temporal sample was clearly separated. The result was confirmed by independent replication of the experiment and could represent an individual variation in this particular sample or an experimental artifact.

To confirm the microarray results, we selected five genes for northern analysis based on their microarray expression profiles. Two showed preferential expression in retina (NEUROD4, DR010030A20H09), two in brain (SYN2, SPP1), and one was equally expressed in retina and brain (DR010024A20G01). Blots of total RNA from retina, brain, and spleen were hybridized with cDNA probes for these five genes (Appendix 1). We found that the northern blots showed the same expression patterns predicted by the microarray data with no detectable signal in spleen for any of the five genes (Figure 4A). Semiquantitative determination of expression in the northern blots correlated closely with the signal pattern obtained from the microarray experiments (Figure 4B).

\section{DISCUSSION}

We have undertaken the first step in the evaluation of the normal canine retinal expression profile to create a system that

\section{A up-regulated}

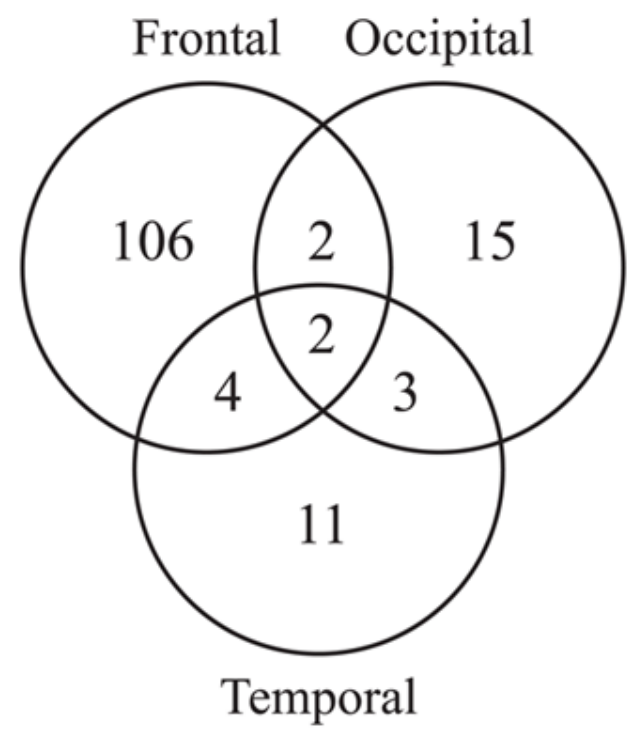

\section{B down-regulated}

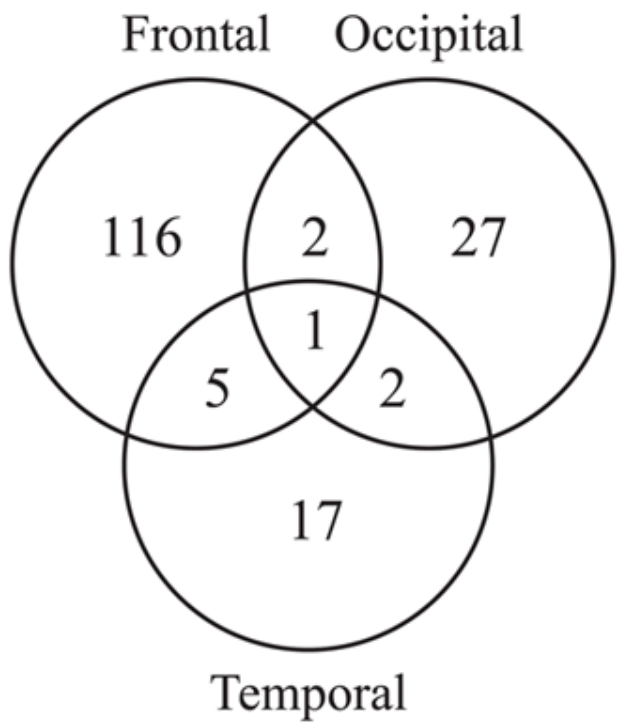

Figure 2. Region-dependent expression pattern for frontal, occipital, and temporal brain cortices. The diagrams show the number of genes up- (A) and downregulated $(\mathbf{B})$ in the respective regions.

\begin{tabular}{|c|c|c|c|c|c|c|c|c|}
\hline $\begin{array}{c}\text { Clone } \\
\text { identifier }\end{array}$ & $\begin{array}{c}\text { GenBank } \\
\text { access } \\
\text { number }\end{array}$ & Dog chromosome location & $\begin{array}{c}\text { Gene } \\
\text { symbol }\end{array}$ & $\begin{array}{l}\text { Gene ID } \\
\text { number }\end{array}$ & $\begin{array}{c}\text { Human } \\
\text { chromosome }\end{array}$ & Unigene & $\begin{array}{l}\text { Retina/brain } \\
\text { fold change }\end{array}$ & Function \\
\hline DR010023A20H05 & DT541102 & $\mathrm{x}: 80,243,963-80,244,545$ & PLP1 & 5354 & $\mathrm{xq} 22.2$ & Hs. 1787 Cfa. 3274 & -25 & Myelination \\
\hline DR010027A10F 10 & DT542045 & $4: 14,326,600-14,327,069$ & SPP1 & 6696 & $4 \mathrm{q} 22.1$ & Hs. 313 & -20 & Phosphoprotein \\
\hline DR010005A20E04 & DT537067 & $32: 13,862,656-13,862,983$ & SPARCL1 & 8404 & $4 \mathrm{q} 22.1$ & Hs. 1424 & -17 & Extracellular matrix protein \\
\hline DR010008A20A02 & DT537874 & $20: 40,129,412-40,129,709$ & NISCH & 11188 & $3 \mathrm{p} 21.1$ & Hs. 435290 & -16 & Cytoskeleton and cellular components \\
\hline DR010010B10C05 & DT538398 & $6: 62,422,039-62,422,316$ & LMO 4 & 8543 & $1 \mathrm{p} 22.3$ & Hs. 436792 & -11 & Transcriptional regulator \\
\hline DP010005000E06 & DT536078 & $20: 9,218,236-9,413,008$ & SYN2 & 6854 & $3 \mathrm{p} 25$ & Hs. 445503 & -9 & Neuronal phosphoproteins \\
\hline DR010027B20A04 & DT542218 & $16: 55,443,443-55,443,919$ & GPM6A & 2823 & $4 \mathrm{q}^{3} 4.2$ & Hs. 75819 & -8 & Myelin proteolipid \\
\hline DR010014B20F03 & DT539277 & $13: 30,167,584-30,167,884$ & DDEF 1 & 50807 & $8 \mathrm{q} 24.21$ & Hs.106015 Cfa.10191 & -6.5 & Signal transduction \\
\hline DR010015A20E10 & DT539376 & $35: 9,024,760-9,025,290$ & NRN1 & 51299 & $6 \mathrm{p} 25.1$ & Hs. 103291 & -6.5 & Neural activity \\
\hline DR010019A20H03 & DT540130 & $24: 15,030,049-15,043,202$ & SNAP 25 & 6616 & $2 \mathrm{p} 12.2$ & Hs. 167317 & -6.5 & Synaptic activity \\
\hline DR010024A10E09 & DT541302 & $26: 31,587,239-31,587,700$ & SEPT5 & 5413 & $22 \mathrm{q} 11.21$ & Hs. 283743 & -6 & Nucleic acids acitivity \\
\hline DR010024B10F 05 & DT541444 & $4: 69,817,413-69,817,666$ & & & $1 \mathrm{q} 43$ & & -6 & EST \\
\hline DR010026A20H08 & DT541827 & $x: 57,663,647-57,664,138$ & GDPD2 & 54857 & $\mathrm{xq} 13.1$ & Hs. 433812 & -5 & Cell differentiation \\
\hline DR010013A10A11 & DT538911 & $13: 52,260,613-52,260,773$ & $\begin{array}{l}\text { IGFBP } 7 \\
\text { I }\end{array}$ & 3490 & $4 \mathrm{q} 12$ & Hs. 479808 & -5 & Insulin-like growth factor \\
\hline DR010022A10B01 & DT540751 & $24: 15,694,097-15,694,559$ & C20orf 103 & 24141 & $20 \mathrm{p} 12.2$ & Hs. 22920 & -4.4 & Protein precursor \\
\hline DR010020A10B08 & DT540252 & $17: 62,843,281-62,843,815$ & MLLT11 & $\begin{array}{l}21141 \\
10962\end{array}$ & $1 \mathrm{q} 21.2$ & Hs. 75823 & -4.2 & leukemogenesis \\
\hline DR010025B10A02 & DT541635 & $\mathrm{x}: 43,640,390-43,640,656$ & & & $10 \mathrm{q} 23.33$ & & -4 & Unknown \\
\hline DR010026B20G05 & DT541971 & $5: 39,939,020-39,939,274$ & & & $17 \mathrm{p} 12$ & & -4 & Unknown \\
\hline DR010025A21C11 & DT541582 & $26: 3,428,348-3,428,585$ & PXMP2 2 & 5827 & $12 \mathrm{q} 24.33$ & Hs. 430299 & -3.6 & Nucleic acitvity \\
\hline DR010015A20E09 & DT539375 & $15: 5,881,332-5,881,851$ & PPT1 & 5538 & $1 \mathrm{p} 34.2$ & Hs. 3873 Cfa. 10158 & -3.6 & Metabolism \\
\hline DR010016B10H12 & DT539539 & $20: 48,103,437-48,103,712$ & & & $19 \mathrm{p} 13.11$ & & -3 & EST \\
\hline DR010005B10E03 & DT537156 & $2: 79,096,079-79,096,475$ & CAMK2N1 & 55450 & $1 \mathrm{p} 36.12$ & Hs. 197922 & -3 & Metabolism \\
\hline DR010012B20D10 & DT539065 & $24: 35,260,072-35,260,236$ & YWHAB & 7529 & $20 \mathrm{p} 13.12$ & Hs. 279920 & -2.5 & Signal transduction \\
\hline DR010020A20D02 & DT540337 & $1: 98,778,726-98,779,224$ & DIRAS2 & 54769 & $9 \mathrm{q} 22.2$ & Hs. 165636 & -2.5 & Metabolism \\
\hline DR010024A20H05 & DT541397 & $10: 52,558,495-52,558,873$ & CALM2 & 805 & $2 \mathrm{p} 21$ & Hs. 468442 & -2.5 & Metabolism \\
\hline DR010010A20G08 & DT538371 & $1: 111,515,746-111,516,031$ & CALM3 & 808 & $19 \mathrm{q} 13.32$ & Hs. 515487 & -2.5 & Metabolism \\
\hline DR010013B10A11 & DT538990 & $4: 12,791,804-12,792,189$ & & & $3 \mathrm{p} 21.31$ & & -2.5 & EST \\
\hline DR010013A10E12 & DT539022 & $3: 32,111,666-32,111,915$ & & & $15 \mathrm{q} 22.2$ & & -2.5 & EST \\
\hline DR010028A20D02 & DT542393 & $16: 22,581,974-22,582,397$ & & & $15 q 14$ & & -2.5 & EST \\
\hline DR010012B20E05 & DT538877 & $11,386,498-11,386,885$ & ATP2A2 & 488 & $12 q 24.11$ & Hs. 506759 & -2.5 & Metabolism \\
\hline
\end{tabular}

The top 30 genes with preferential brain expression in a retina-brain pool comparison are listed, with the corresponding identifiers, chromosomal location, expression ratio, and function. Hs represents Homo sapiens, Cfa represents Canis familiaris. 
allows comparison within and between different models of retinal degeneration. For this purpose, a reference design was chosen, which, ideally, would utilize a pool of normal retina as reference. It is not possible, however, to provide a retina pool that is large enough for the proposed scale of experiments, and, therefore, was substituted by a brain pool. The limitation of this reference is that genes not expressed in the brain cannot be validated against this common reference, and common data analysis procedures, such as normalization, might introduce experimental errors based on the tissue-specific differences. This study has validated the procedure, and identified potential problematic genes which subsequently can be investigated in alternate approaches such as quantitative RT-PCR or macroarrays [26] that selectively target for analysis those genes not expressed in the brain pool.

Microarray data are most commonly normalized using the loess algorithm, which assumes that only a small percentage of genes is differentially expressed, and maintains balance between the numbers of up- and downregulated expressed transcripts. Alternative approaches for normalization procedures propose the use of ANOVA models [27]. This method essentially performs only a global normalization, and does not correct for intensity or scale differences. Yang et al. [24] have found that the standard global median normalization can often be inadequate due to spatial and intensity dependent dye biases, and proposed loess subgrid normalization. We have applied different models to our data (Appendix 1), which further support these findings and suggests that we do not introduce experimental bias in the data by applying the loess subgrid normalization.
As an initial step in evaluating the microarray, we examined gene expression pattern differences between normal retina and the brain pool tissue reference sample. These comparisons allowed us to identify 405 out of 3,070 valid transcripts $(13.2 \%)$ as preferentially expressed in retina (Table 1), and 452 genes with low abundance in the retina (Table 2). As expected, known photoreceptor genes were highly expressed in retina, demonstrating the specificity of the hybridization. Over a third of the differentially expressed clones represent potentially novel genes that are enriched or even specific to retina or brain [28]. Among the differential expressed genes were many important to neural activity, such as ion channels (transport class) and cytoskeletal proteins (structural class). Genes involved in more general processes, such as energy generation, also showed retina or brain preferred expression. Compared to the total number of genes with preferential expression, we found higher frequencies of proliferation and cell death genes expressed in the brain than retina, and nucleic acid processing genes in retina than brain. Among the transcripts preferentially expressed in the brain were many known and unknown genes not previously reported to have a preferential expression pattern in different regions of the brain $[5,29]$. We demonstrated also that expression patterns are quite restricted to individual cortex areas, as few differential expressed genes showed overlap between the examined brain regions (Figure 2).

It is clear that, despite the common embryonic origin of retina and brain tissues, the corresponding expression profiles differ. Even though a subset of the genes expressed in each of the three brain regions were unique to the tissue of origin, this

TABle 3. Genes UPREgulated AND EXPRESSED IN TWO OR THREE BRAIN CORTICES

\begin{tabular}{|c|c|c|c|c|c|c|c|c|}
\hline $\begin{array}{c}\text { Clone } \\
\text { identifier }\end{array}$ & $\begin{array}{r}\text { GenBank } \\
\text { access } \\
\text { number }\end{array}$ & Dog chromosome location & $\begin{array}{c}\text { Gene } \\
\text { symbol }\end{array}$ & $\begin{array}{l}\text { Gene ID } \\
\text { number }\end{array}$ & $\begin{array}{c}\text { Human } \\
\text { chromosome }\end{array}$ & Unigene & $\begin{array}{l}\text { Overlapping } \\
\text { regions }\end{array}$ & Function \\
\hline DR010026A10E12 & DT541032 & $1: 75,209,657-75,209,810$ & C1orf 63 & 57035 & $1 \mathrm{p} 36.11$ & Hs.259412 Cfa.10157 & $\mathrm{F}-\mathrm{O}$ & Open reading frame \\
\hline DR010027A10B02 & DT541999 & $9: 7,065,312-7,065,859$ & & & $17 \mathrm{q} 24.2$ & & $\mathrm{~F}-\mathrm{O}$ & EST \\
\hline DR010023B10A04 & DT541111 & $22: 64,149,260-64,149,794$ & UPF 3A & 65110 & $13 q 34$ & Hs. 533855 & $F-T$ & Metabolism \\
\hline DR010019B10C12 & DT540150 & $12: 7,009,358-7,009,914$ & & & $6 \mathrm{p} 21.31$ & & $F-T$ & EST \\
\hline DR010017A10B01 & DT539606 & $8: 50,712,025-50,712,500$ & KIAA0 317 & 9870 & $14 \mathrm{q} 24.3$ & Hs. 497417 & $F-T$ & Unknown \\
\hline DR010018B10B12 & DT539606 & $27: 40,457,438-40,457,926$ & NECAP1 & 25977 & $12 \mathrm{p} 13.31$ & Hs. 555927 & $F-T$ & Involved in endocytosis \\
\hline DR010023B10B01 & DT541120 & $18: 59,559,359-59,559,613$ & & & $7 \mathrm{q} 21.3$ & & $0-T$ & EST \\
\hline DR010012B10B11 & DT541128 & $10: 14,366,170-14,366,540$ & CPSF 6 & 11052 & 12 q15 & Hs. 369606 & O-T & Nucleic acids \\
\hline DR010010B20H09 & DT538497 & $7: 12,476,293-12,476,485$ & & & $14 \mathrm{q} 23.1$ & & $0-T$ & EST \\
\hline DR010012A10F 04 & DT538700 & $9: 11,033,436-11,033,709$ & & & $11 \mathrm{q} 13.1$ & & $F-0-T$ & EST \\
\hline DR010009B20B10 & DT538214 & $23: 47,202,203-47,202,727$ & TM4SF 1 & 4071 & $3 \mathrm{q} 25.1$ & Hs. 351316 & $\mathrm{~F}-\mathrm{O}-\mathrm{T}$ & Metabolism \\
\hline
\end{tabular}

Hs represents Homo sapiens, Cfa represents Canis familiaris, F represents Frontal, O represents Occipital, T represents Temporal.

TABLE 4. GENES DOWNREgUlated AND EXPRESSED IN TWO OR THREE BRAIN CORTICES

\begin{tabular}{|c|c|c|c|c|c|c|c|c|}
\hline Clone identifier & $\begin{array}{l}\text { Genbank } \\
\text { access }\end{array}$ & Dog chromosome location & $\begin{array}{c}\text { Gene } \\
\text { symbol }\end{array}$ & $\begin{array}{l}\text { Gene ID } \\
\text { number }\end{array}$ & $\begin{array}{c}\text { Human } \\
\text { chromosome }\end{array}$ & Unigene & $\begin{array}{l}\text { Overlapping } \\
\text { regions }\end{array}$ & Function \\
\hline DR010006A10H12 & DT537289 & $32: 35,442,842-35,442,964$ & & & $4 q 25$ & & F-O & EST \\
\hline DR010027B10G05 & DT542201 & $\mathrm{X}: 62,967,726-62,968,008$ & ATRX & 546 & $\mathrm{Xq} 21.2$ & $\begin{array}{c}\text { Hs. } 533523 \\
\text { Cfa. } 2632\end{array}$ & F-O & Transcriptional regulator factor \\
\hline DR010014A10D04 & DT539133 & $24: 28,803,524-28,803,789$ & RPN2 & 6185 & $20 \mathrm{q} 11.23$ & Hs. 370895 & F-T & Metabolism \\
\hline DR010009B10C03 & DT538133 & $2: 5,292,568-5,293,107$ & & & $5 q 14.3$ & & F-T & EST \\
\hline DR010014B10D06 & DT539212 & $2: 81,584,176-81,584,587$ & RCC2 & 55920 & $1 \mathrm{p} 36.13$ & Hs. 380857 & F-T & Cell division \\
\hline DR010022A20D11 & DT540746 & $24: 28,877,230-28,877,628$ & MANBAL & 63905 & $20 q 11.20$ & Hs. 6126 & F-T & Metabolism \\
\hline DR010025A10A04 & DT541537 & $25: 22,008,506-22,008,977$ & & & $12 \mathrm{q} 13.11$ & & F-T & EST \\
\hline DR010012B10A09 & DT538775 & $12: 67,729,356-67,729,566$ & FLJ10159 & 55084 & $6 \mathrm{q} 21$ & Hs. 445244 & F-O-T & Unknown \\
\hline DR010007B20E10 & DT537769 & $14: 61,667,805-61,668,179$ & ING3 & 54556 & $7 \mathrm{q} 31.33$ & Hs. 489811 & O-T & DNA binding \\
\hline DR010012B10B11 & DT538789 & $10: 14,366,170-14,366,540$ & CPSF6 & 11052 & $12 q 15$ & Hs. 369606 & O-T & Nucleic acid binding \\
\hline
\end{tabular}

Hs represents Homo sapiens; Cfa represents Canis familiaris; F represents frontal; T represents temporal; O represents occipital. 

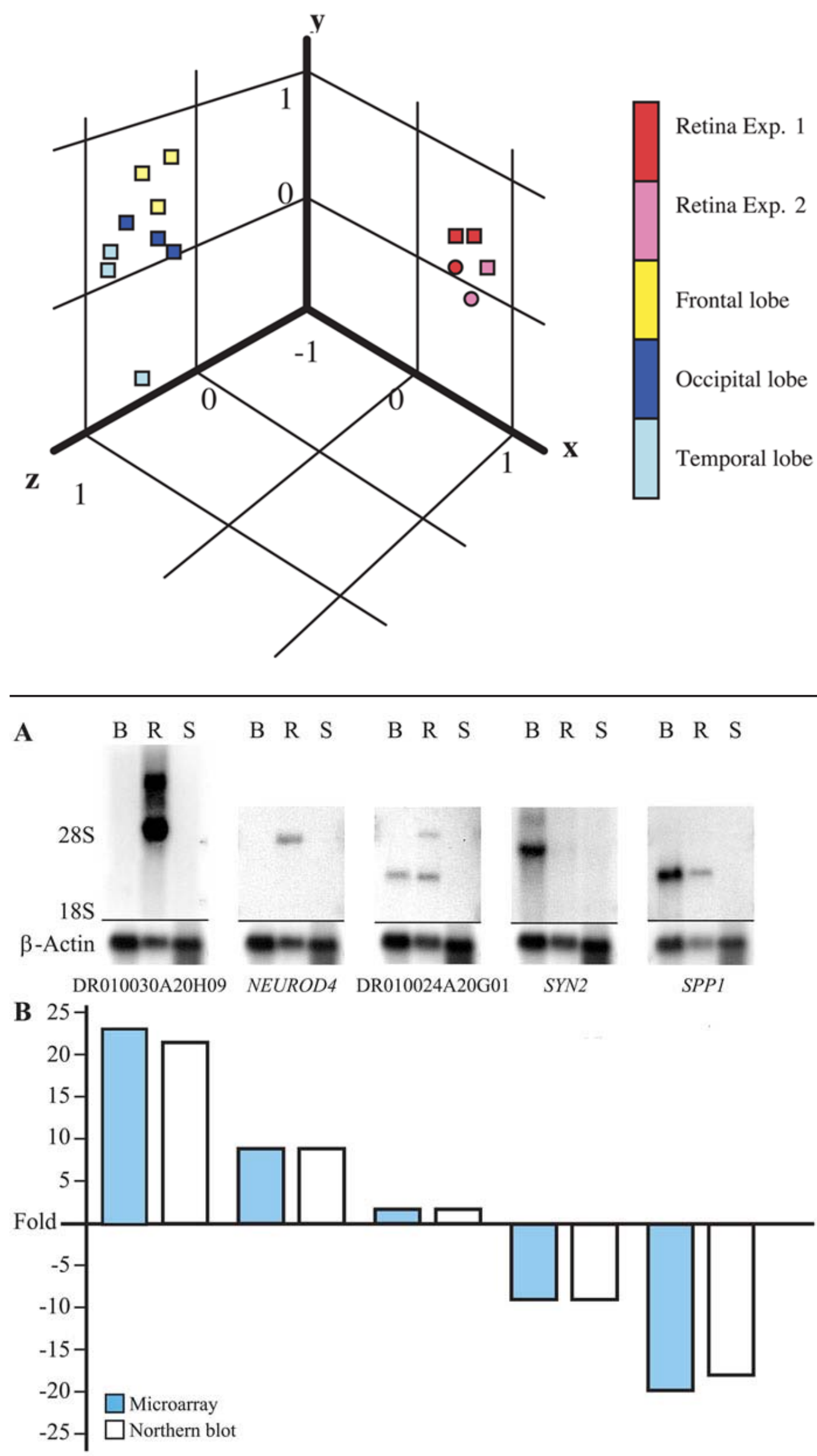

Figure 4. Northern blot validation of selected genes. A: Expression profile for selected genes was obtained from northern analysis using brain (B), retina (R), and spleen (S) through normalization against the canine $\beta$-actin loading control, and compared to microarray results (B). NEUROD4: neurogenic differentiation 4; SYN2: synapsin II; SPP1: secreted phosphoprotein 1. 
was proportionately a small part of the total number of genes examined. Overall, the gene expression profiles of the three brain regions clustered closely, when compared to the different profile obtained from retina (Figure 3). The PCA also illustrates strong similarities in each of the replicates for a given tissue, showing the sensitivity and robustness of the custom cDNA microarray. Particularly for the retina, we did not observe significant differences in expression profiles between 16 week old dogs based on gender or litter as has previously been suggested from human studies [14].

Results of the microarray work were validated on northern analysis for individual transcripts (Figure 4) and confirmed to reflect the physiology of the analyzed tissues. For example, we found that NEUROD4 had an increased expression level in retina compared to brain according with its function in the developing mammalian retina [30]. $C D K N 1 B$ was equally expressed in normal retina and brain tissues; this gene encodes a protein that binds to and prevents the activation of cyclin ECDK2 or cyclin D-CDK4 complexes, and thus controls the cell cycle progression at G1. The microarray results also identified ESTs representing potential novel genes that showed high preferential levels of expression in retina (e.g., DR010020A10D06, DR10030A20H09; Table 1). These novel genes of still unknown function are currently under further investigation as they may play critical roles in retinal development or maintenance, and are potential candidate genes for retinal disorders.

Recent expression studies conducted for human retina utilized the comparisons to different tissues, such as brain, liver, or kidney across SAGE, cDNA library, and microarray platforms [31,32]. In each case, the results yielding a few hundred retina-enriched genes can be classified into three different types: 1-genes already known to be retina enriched, such as guanine nucleotide binding protein (GNAT1) and arrestin (ARR3); 2-characterized genes previously not known to be retina enriched, such as WNT inhibitory factor 1 (WIFl) and frizzled-related protein $(F R Z B)$, and 3-unknown genes, mostly EST clusters. Our data are not just comparable to those studies in terms of identified classes and the ratio of genes specific to the retina, but provide additional information for potential novel genes integrated in the original EST database that allows the subsequent characterization of these transcripts [16].

It has been suggested that genes involved in developmental regulation of the retina are among the top candidates for degenerative processes when mutated. Recently, a microarray profile between wild type and $\mathrm{Nrl}^{-/}$mouse retinas produced a list of 1,000 genes with potential high influence in rod development [33]. Among those were several genes associated with human retinopathies (e.g., GNAT1, RHO, SAG, ROM1, $P D E 6 B)$ that have also been identified through our analysis (Table 1, Appendix 1). Furthermore, this work presents comparable percentage of genes involved in metabolic pathways and unknown genes, suggesting that our microarray results are a suitable model system to address retina-specific biological questions. The results can now be extended to examine the gene expression profiles of different canine retinal degenera- tion models aiming to differentiate those pathways that are unique and mutation-specific from those that are mutationindependent and common to several of the retinal disorders. This approach will provide new insights into the molecular mechanisms of these diseases, and help identify key molecules and pathways for therapeutic intervention.

\section{ACKNOWLEDGEMENTS}

We would like to acknowledge Don A. Baldwin, PhD, director of the Penn Microarray Facility, School of Medicine, University of Pennsylvania, for discussion and assistance with the microarray experiments and scanning analysis, and undergraduate student Charles Owen Smith for data analysis and entry. We also are grateful to John Tobias, PhD, from the Penn Bioinformatics Core, University of Pennsylvania for helping with PCA and SAM analysis. This work was supported by NEI/NIH grants R01EY13132, R01EY06855, P30EY001583 The Foundation Fighting Blindness, The Laura J. Niles Foundation, The Van Sloun Fund for Canine Genetic Research, and Pfizer, Inc.

\section{REFERENCES}

1. Aguirre GD, Acland GM. Models, mutants and man: searching for unique phenotypes and genes in the dog model of inherited retinal degeneration. In: Ostrander EA, Giger U, Lindblad-Toh K, editors. The dog and its genome. Cold Spring Harbor (NY): Cold Spring Harbor Laboratory Press; 2006. p. 291-325.

2. Portera-Cailliau C, Sung CH, Nathans J, Adler R. Apoptotic photoreceptor cell death in mouse models of retinitis pigmentosa. Proc Natl Acad Sci U S A 1994; 91:974-8.

3. Chang GQ, Hao Y, Wong F. Apoptosis: final common pathway of photoreceptor death in rd, rds, and rhodopsin mutant mice. Neuron 1993; 11:595-605.

4. Wenzel A, Grimm C, Samardzija M, Reme CE. Molecular mechanisms of light-induced photoreceptor apoptosis and neuroprotection for retinal degeneration. Prog Retin Eye Res 2005; 24:275-306.

5. Hackam AS, Strom R, Liu D, Qian J, Wang C, Otteson D, Gunatilaka T, Farkas RH, Chowers I, Kageyama M, Leveillard T, Sahel JA, Campochiaro PA, Parmigiani G, Zack DJ. Identification of gene expression changes associated with the progression of retinal degeneration in the rd1 mouse. Invest Ophthalmol Vis Sci 2004; 45:2929-42.

6. Rattner A, Sun H, Nathans J. Molecular genetics of human retinal disease. Annu Rev Genet 1999; 33:89-131.

7. Pacione LR, Szego MJ, Ikeda S, Nishina PM, McInnes RR. Progress toward understanding the genetic and biochemical mechanisms of inherited photoreceptor degenerations. Annu Rev Neurosci 2003; 26:657-700.

8. Shalon D, Smith SJ, Brown PO. A DNA microarray system for analyzing complex DNA samples using two-color fluorescent probe hybridization. Genome Res 1996; 6:639-45.

9. Schena M, Shalon D, Heller R, Chai A, Brown PO, Davis RW. Parallel human genome analysis: microarray-based expression monitoring of 1000 genes. Proc Natl Acad Sci U S A 1996; 93:10614-9.

10. Yoshida S, Yashar BM, Hiriyanna S, Swaroop A. Microarray analysis of gene expression in the aging human retina. Invest Ophthalmol Vis Sci 2002; 43:2554-60.

11. Whitney LW, Becker KG, Tresser NJ, Caballero-Ramos CI, Munson PJ, Prabhu VV, Trent JM, McFarland HF, Biddison WE. 
Analysis of gene expression in mutiple sclerosis lesions using cDNA microarrays. Ann Neurol 1999; 46:425-8.

12. Alizadeh M, Gelfman CM, Bench SR, Hjelmeland LM. Expression and splicing of FGF receptor mRNAs during ARPE-19 cell differentiation in vitro. Invest Ophthalmol Vis Sci 2000; 41:235762.

13. Swaroop A, Zack DJ. Transcriptome analysis of the retina. Genome Biol 2002; 3:REVIEWS1022.

14. Chowers I, Liu D, Farkas RH, Gunatilaka TL, Hackam AS, Bernstein SL, Campochiaro PA, Parmigiani G, Zack DJ. Gene expression variation in the adult human retina. Hum Mol Genet 2003; 12:2881-93.

15. Buraczynska M, Mears AJ, Zareparsi S, Farjo R, Filippova E, Yuan Y, MacNee SP, Hughes B, Swaroop A. Gene expression profile of native human retinal pigment epithelium. Invest Ophthalmol Vis Sci 2002; 43:603-7.

16. Zangerl B, Sun Q, Pillardy J, Johnson JL, Schweitzer PA, Hernandez AG, Liu L, Acland GM, Aguirre GD. Development and characterization of a normalized canine retinal cDNA library for genomic and expression studies. Invest Ophthalmol Vis Sci 2006; 47:2632-8.

17. Bowes C, van Veen T, Farber DB. Opsin, G-protein and 48-kDa protein in normal and rd mouse retinas: developmental expression of mRNAs and proteins and light/dark cycling of mRNAs. Exp Eye Res 1988; 47:369-90.

18. Farber DB, Danciger JS, Organisciak DT. Levels of mRNA encoding proteins of the cGMP cascade as a function of light environment. Exp Eye Res 1991; 53:781-6.

19. McGinnis JF, Austin BJ, Stepanik PL, Lerious V. Light-dependent regulation of the transcriptional activity of the mammalian gene for arrestin. J Neurosci Res 1994; 38:479-82.

20. Korenbrot JI, Fernald RD. Circadian rhythm and light regulate opsin mRNA in rod photoreceptors. Nature 1989; 337:454-7.

21. Huang JC, Chesselet MF, Aguirre GD. Decreased opsin mRNA and immunoreactivity in progressive rod-cone degeneration (prcd): cytochemical studies of early disease and degeneration. Exp Eye Res 1994; 58:17-30.

22. Huang H, Frank MB, Dozmorov I, Cao W, Cadwell C, Knowlton $\mathrm{N}$, Centola M, Anderson RE. Identification of mouse retinal genes differentially regulated by dim and bright cyclic light rearing. Exp Eye Res 2005; 80:727-39.

23. Zangerl B, Zhang Q, Acland GM, Aguirre GD. Characterization of three microsatellite loci linked to the canine RP3 interval. J Hered 2002; 93:70-3.

24. Yang YH, Dudoit S, Luu P, Lin DM, Peng V, Ngai J, Speed TP. Normalization for cDNA microarray data: a robust composite method addressing single and multiple slide systematic variation. Nucleic Acids Res 2002; 30:e15.

25. Tusher VG, Tibshirani R, Chu G. Significance analysis of microarrays applied to the ionizing radiation response. Proc Natl
Acad Sci U S A 2001; 98:5116-21. Erratum in: Proc Natl Acad Sci U S A 2001; 98:10515.

26. Zhao SH, Nettleton D, Liu W, Fitzsimmons C, Ernst CW, Raney NE, Tuggle CK. Complementary DNA macroarray analyses of differential gene expression in porcine fetal and postnatal muscle. J Anim Sci 2003; 81:2179-88.

27. Kerr MK, Martin M, Churchill GA. Analysis of variance for gene expression microarray data. J Comput Biol 2000; 7:819-37.

28. Chowers I, Gunatilaka TL, Farkas RH, Qian J, Hackam AS, Duh E, Kageyama M, Wang C, Vora A, Campochiaro PA, Zack DJ. Identification of novel genes preferentially expressed in the retina using a custom human retina cDNA microarray. Invest Ophthalmol Vis Sci 2003; 44:3732-41.

29. Thomson SA, Kennerly E, Olby N, Mickelson JR, Hoffmann DE, Dickinson PJ, Gibson G, Breen M. Microarray analysis of differentially expressed genes of primary tumors in the canine central nervous system. Vet Pathol 2005; 42:550-8.

30. Strausberg RL, Feingold EA, Grouse LH, Derge JG, Klausner RD, Collins FS, Wagner L, Shenmen CM, Schuler GD, Altschul SF, Zeeberg B, Buetow KH, Schaefer CF, Bhat NK, Hopkins RF, Jordan H, Moore T, Max SI, Wang J, Hsieh F, Diatchenko L, Marusina K, Farmer AA, Rubin GM, Hong L, Stapleton M, Soares MB, Bonaldo MF, Casavant TL, Scheetz TE, Brownstein MJ, Usdin TB, Toshiyuki S, Carninci P, Prange C, Raha SS, Loquellano NA, Peters GJ, Abramson RD, Mullahy SJ, Bosak SA, McEwan PJ, McKernan KJ, Malek JA, Gunaratne PH, Richards S, Worley KC, Hale S, Garcia AM, Gay LJ, Hulyk SW, Villalon DK, Muzny DM, Sodergren EJ, Lu X, Gibbs RA, Fahey J, Helton E, Ketteman M, Madan A, Rodrigues S, Sanchez A, Whiting M, Madan A, Young AC, Shevchenko Y, Bouffard GG, Blakesley RW, Touchman JW, Green ED, Dickson MC, Rodriguez AC, Grimwood J, Schmutz J, Myers RM, Butterfield YS, Krzywinski MI, Skalska U, Smailus DE, Schnerch A, Schein JE, Jones SJ, Marra MA, Mammalian Gene Collection Program Team. Generation and initial analysis of more than 15,000 fulllength human and mouse cDNA sequences. Proc Natl Acad Sci U S A 2002; 99:16899-903.

31. Qian J, Esumi N, Chen Y, Wang Q, Chowers I, Zack DJ. Identification of regulatory targets of tissue-specific transcription factors: application to retina-specific gene regulation. Nucleic Acids Res 2005; 33:3479-91.

32. Hackam AS, Qian J, Liu D, Gunatilaka T, Farkas RH, Chowers I, Kageyama M, Parmigiani G, Zack DJ. Comparative gene expression analysis of murine retina and brain. Mol Vis 2004; 10:637-49.

33. Akimoto M, Cheng H, Zhu D, Brzezinski JA, Khanna R, Filippova E, Oh EC, Jing Y, Linares JL, Brooks M, Zareparsi S, Mears AJ, Hero A, Glaser T, Swaroop A. Targeting of GFP to newborn rods by Nrl promoter and temporal expression profiling of flowsorted photoreceptors. Proc Natl Acad Sci U S A 2006; 103:38905.

The appendix is available in the online version of this article at http://www.molvis.org/molvis/v12/a118/.

The print version of this article was created on 7 Sep 2006. This reflects all typographical corrections and errata to the article through that date. Details of any changes may be found in the online version of the article. 